\title{
Influence of substrates, light, filter paper and pH on the sporulation of Cercospora sojina*
}

\author{
Diana Erica Gómez'; Erlei Melo Reis ${ }^{2}$
}

${ }^{1}$ INTA EEA Sáenz Peña, Ruta 95 Km 1108, Presidencia Roque Sáenz Peña, Chaco. Argentina. C. P. 3700. ${ }^{2}$ FAMV/UPF, Laboratório de Fitopatologia, Campus I - CP. 611. Passo Fundo, RS. *Parte da Dissertação de Mestrado do primeiro autor. Autor para correspondência: Diana Erica Gómez (diananeg@hotmail.com)

Data de chegada: 30/09/2011. Aceito para publicação em: 13/04/2013.

\section{ABSTRACT}

Gómez, D. E.; Reis, E.M. Influence of substrates, light, filter paper and pH on the sporulation of Cercospora sojina. Summa Phytopathologica, v.39, n.2, p.126-129, 2013.

Fungi require special substrates for their isolation, vegetative growth and sporulation. In experiments conducted in the laboratory, the influence of substrates, light, filter paper and $\mathrm{pH}$ on the sporulation of Cercospora sojina conidia, the causal agent of soybean frogeye leaf spot, was assessed. The media potato sucrose agar, V-8 agar, tomato extract agar, soybean leaf extract agar, soybean seed extract agar, soybean meal agar, soybean flour agar and wheat flour agar were tested, added on the surface, with and without filter paper and under two light regimes, with $12 \mathrm{~h}$ light at $25^{\circ} \pm 2^{\circ} \mathrm{C}$ and in the dark. A triple factorial $8 \times 2 \times 2$ (substrates $\mathrm{x}$ light/dark $\mathrm{x}$ with/without filter paper) design with four replicates was used. V-8 agar medium was employed and the $\mathrm{pH}$ was adjusted with $\mathrm{HCl} 0.1 \mathrm{~N}$ or $\mathrm{NaOH} 0.1 \mathrm{~N}$ before autoclaving to the values: $3,4,5,6,7$ and 8 , and the $\mathrm{pH}$ of V-8 agar medium is 6.7. The evaluation was done on the seventh day of incubation. Data underwent regression analysis. Sporulation was maximized on the agar media V-8, seed extract, oat flour, tomato extract, and potato sucrose in the presence of filter paper and $12 \mathrm{~h}$ light. On V-8 medium, maximal sporulation was obtained with $\mathrm{pH}$ 6.7.

Additional keywords: Inoculum production, nutrition, soybean, Glycine max.

\section{RESUMO}

Gómez, D.E.; Reis, E.M. Influência de substratos, luz, papel de filtro e pH na esporulação de Cercospora sojina. Summa Phytopathologica, v.39, n.2, p.126-129, 2013.

Os fungos requerem substratos especiais para seu isolamento, crescimento vegetativo e esporulação. Em experimentos conduzidos no laboratório foram avaliadas a influência de substratos, luz, papel de filtro e pH na esporulação de conídios de Cercospora sojina agente causal da mancha foliar olho-de-rã da soja. Foram testados os meios ágar batata sacarose, ágar V-8, ágar extrato de tomate, ágar extrato de folha de soja, ágar grãos de soja, ágar farelo de soja, ágar farinha soja e ágar farinha de aveia, acrescidos na superfície com e sem papel de filtro e submetidos a dois regimes luminosos, com luz de $12 \mathrm{~h}$ a $25^{\circ} \pm 2^{\circ} \mathrm{C}$ e sem luz. O delineamento experimental usado foi fatorial triplo $8 \times 2 \times 2$ (substratos $\times$ luz/escuro $\times$ com/sem papel de filtro), com quatro repetições distribuídas ao acaso. Usou-se o meio ágar V-8 ajustando o $\mathrm{pH}$ com $\mathrm{HCl} 0.1 \mathrm{~N}$ ou $\mathrm{NaOH} 0.1 \mathrm{~N}$ antes da autoclavagem nos valores: $3 ; 4 ; 5 ; 6 ; 7$ e 8 , sendo o $\mathrm{pH}$ do meio ágar V-8 de 6.7. A avaliação foi realizada aos sete dias de incubação. Os dados foram submetidos à análise da regressão. A esporulação foi maximizada nos meios V-8, ágar extrato de semente, farinha de aveia, extrato de tomate e batata sacarose ágar na presença de papel de filtro e fotoperíodo de $12 \mathrm{~h}$. No meio V-8 a máxima esporulação foi obtida com o pH 6.7.

Palavras-chave adicionais: Produção de inóculo, nutrição, soja, Glycine max.

Brazil had an estimated soybean production of 68.55 million tons in the 2010/2011 growing season (7). In Argentina, the soybean has become a major crop with rapid expansion from the 70's to the 80 's. At the moment, its productivity is of $2,660 \mathrm{~kg} / \mathrm{ha}$ and the growing area, of 18.8 million (12).

Soybean frogeye leaf spot (SFLS), caused by the fungus Cercospora sojina Hara, has led susceptible cultivars to damages of $31 \%$ due to the reduction in the photosynthetic leaf area caused by necrotic spots and/or early defoliation (3).

This disease, of epidemic characteristics, occurred in 2008/2009 and 2009/2010 growing seasons in soybean crops at the provinces of Cordoba and Santa Fé, Argentina. It was more severe for genotypes of short and intermediate cycles than in those of long cycle and severity reached $30-60 \%$ leaf area (6).

The substrate for studying fungi must contain all nutrients necessary to stimulate growth, such as carbon sources (carbohydrates), nitrogen sources, minerals and vitamins. There are several types of substrates, some of which are natural and include fruit juice, vegetables or grain infusion (8). The most common substrate is potato dextrose agar (PDA) since it favors the growth of most fungi, although not of all (1).

When the fungus $C$. sojina is produced in laboratory, it sporulates well in V-8 agar and oat flour agar substrates and under exposure of the colony to $12 \mathrm{~h}$ light (15). 


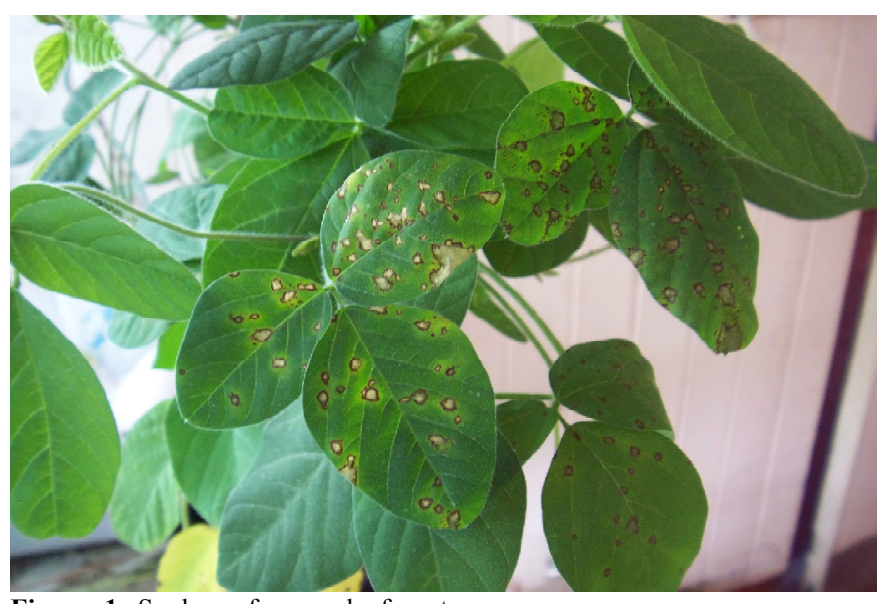

Figure 1. Soybean frogeye leaf spot.

Filter paper added to agar media increases the sporulant surface (Figure 2). This was noted for Helminthosporium spp. when a filter paper layer was added to the top of the agar medium $(10,5)$. The same effect was observed for Alternaria zinniae Pape and Colletotrichum gaminicola (Ces.) Wils. $(11,13)$.

Besides the nutritional components, the $\mathrm{pH}$ of the substrate can have an effect on sporulation. The fungus generally tolerates a wide range of $\mathrm{pH}$, varying from 2 to 9 . For most fungi, the optimum $\mathrm{pH}$ is around 5.6 (8). For $C$. sojina fungus, no references were found concerning $\mathrm{pH}$ influence on sporulation and spore germination (15).

The aim of this study was to quantify the sporulation of $C$. sojina on different substrates, with and without the presence of filter paper, and under light and dark.

\section{MATERIALS AND METHODS}

The experiments were conducted in the Regional Laboratory of Plant Pathology, "Estación Experimental Agropecuaria (EEA) Sáenz Peña, Instituto Nacional de Tecnología Agropecuaria (INTA)", Argentina Republic, and in the Laboratory of Phytopathology and greenhouse of the Faculty of Agronomy and Veterinary Medicine, of the University of Passo Fundo - RS, Brazil.

Influence of culture media, filter paper and light on the sporulation of Cercospora sojina.

The following substrates were tested: potato sucrose agar, V-8 agar (14), tomato extract agar, soybean leaf extract agar (REIS*), soybean seed extract agar (REIS*), soybean meal agar (REIS*), soybean flour agar (REIS*), oat flour agar (9). The effect of adding a filter paper layer to the top of the medium, with and without light, was quantified for $C$. sojina sporulation.

The inoculum used throughout this study was isolated from soybean affected leaves collected from farms in the Pampean Region of Argentina.

Twenty plastic Petri plates $(9.0 \mathrm{~cm}$ diameter) were prepared for each culture medium. Ten plates received sterilized filter paper circles on the surface of substrates. Ten other plates did not receive filter paper. Half of those treatments, with and without filter paper, were kept under $12 \mathrm{~h}$ photoperiod in a growth chamber, where light was provided by four fluorescent lamps OSRAM Universal, 40 watts, at $40 \mathrm{~cm}$ from the surface of plates (Figure 3 ). The other half of treatments was maintained in the dark (Figure 4), surrounded by aluminum foil. All plates were kept at the same temperature $\left(25 \pm 2^{\circ} \mathrm{C}\right)$, remaining in the chamber for 15 days.

After the incubation period and with the aid of a camel brush No.20, the spores were removed by adding $5 \mathrm{~mL}$ of sterile distilled water to each plate. A micropipette was used to transfer $5 \mathrm{~mL}$ to test tubes containing $10 \mathrm{~mL}$ of water. Of this suspension, $10 \mu \mathrm{L}$ were placed on a glass slide and covered with a cover slip. The spores were counted at this volume under an optical microscope with 40x magnitude.

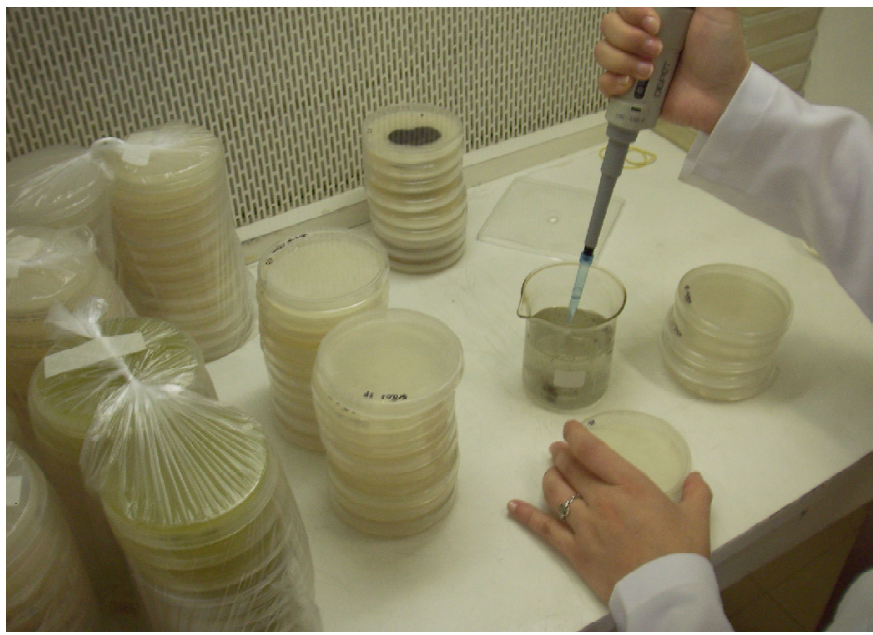

Figure 2. Culture media with and without filter paper

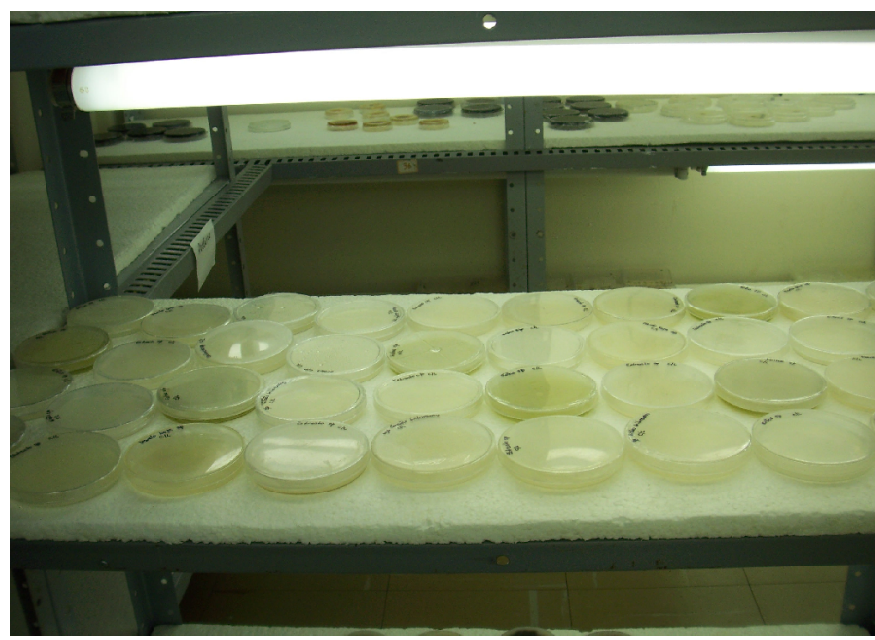

Figure 3. Treatments in a growth chamber with light

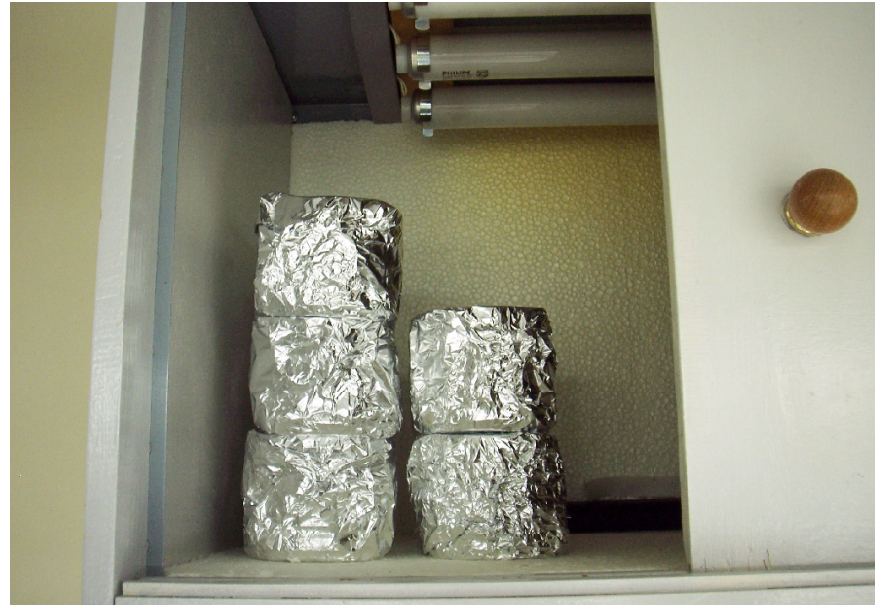

Photo 4. Treatments in the dark 
This procedure was repeated four times for each experimental unit and the average was used to determine the number of conidia. $\mathrm{mL}^{-1}$. The final spore number was estimated per $\mathrm{cm}^{2}$.

Experimental design was in triple factorial $8 \times 2 \times 2$ (substrates $\mathrm{x}$ light/dark $x$ with/without filter paper) with four replicates at random. Data were subjected to Tukey's test at 5\% significance. Each experiment was repeated twice.

Influence of the pH of substrates on the sporulation of Cercospora sojina.

The isolate tested in this study was provided by "Embrapa-soja". In this experiment, V-8 agar substrate was used, and the $\mathrm{pH}$ was adjusted with $\mathrm{HCL} 0.1 \mathrm{~N}$ or $\mathrm{NaOH} 0.1 \mathrm{~N}$, before autoclaving, to the following values: $3,4,5,6,7$ and 8 . The $\mathrm{pH}$ was determined by using a $\mathrm{pH}$ meter PHS-3B Labmeter Model PH2.

The preparation, isolation and incubation conditions of the spore suspension were similar to those of the previous test, but the assessment was done on the seventh day of incubation.

Experimental design was in randomized blocks with four replicates and the data were subjected to regression analysis.

\section{RESULTS AND DISCUSSION}

Influence of culture media, paper filter and light on the sporulation of Cercospora sojina.

As shown in Table 1, there was interaction between substrates and within treatments. The factor light was significant only in the presence of filter paper $(\mathrm{F}=1.0755)$. The interaction substrate $\mathrm{x}$ paper $\mathrm{x}$ light was significant at $5 \%$ probability $(\mathrm{F}=2.3155)$.

Results demonstrated that this fungus sporulates on all culture media. However, the number of produced spores was highly variable according to the different treatments (15).

No references were found in the literature for the effect of filter paper in inducing C. sojina sporulation. Similarly, there is no report in the literature of the effects of seed extract agar, tomato extract agar, soybean flour agar, soybean meal agar and soybean leaf extract agar .

The substrates PDA, soybean seed extract agar, tomato extract agar, oat flour agar and V-8 agar showed good results when exposed to light and with filter paper.

For the treatment with light and without filter paper, the substrates PSA, tomato extract, soybean meal agar and soybean flour favored the sporulation.

When the substrates were kept in the dark and with filter paper, the substrates PDA, leaf extract agar, seed extract agar, tomato extract agar and soybean flour agar were most efficient in inducing sporulation.

Regardless the filter paper, these data are consistent with the results found by Veiga (15), who demonstrated the sporulationinducing effect on V-8 agar and oat flour agar.

Since V-8 agar is not always available, alternative substrates should be obtained. The use of soybean extract agar, seed extract agar, tomato extract agar, oat flour agar with addition of filter paper is of low cost and easy preparation.

Influence of the $\mathbf{p H}$ of substrates on the sporulation of Cercospora sojina

At $\mathrm{pH} 3$ and 4, the evaluation could not be performed because the V-8 medium did not solidify.

The obtained function $y=-2,854.7 x^{2}+38,014.46 x-117.375,25$ in the regression graph $\left(\mathrm{R}^{2}=0.63\right)$ was used to estimate the $\mathrm{pH} 6.7$ at which sporulation was maximum (Figure 5). This finding differs from those obtained by Aguirre (2), who evaluated the effect of $\mathrm{pH}$ on the sporulation of Nomuraea rileyi (Farlow) Samson. These authors did not observe significant effect on conidial production, although the greatest sporulation was obtained at $\mathrm{pH} 6$.

There are few studies about $\mathrm{pH}$ effect on $C$. sojina sporulation.

\section{FINAL REMARKS}

The fungus $C$. sojina sporulates well on different substrates. The sporulation of $C$. sojina can be maximized by using PDA, soybean extract agar, soybean seed extract agar, tomato extract agar, oat meal agar and V-8 agar with filter paper, under light. Maximum sporulation was obtained at $\mathrm{pH} 6.7$ on $\mathrm{V}-8$ agar at $25 \pm 2^{\circ} \mathrm{C}$.

Table 1. Influence of culture media, light and filter paper on the sporulation of Cercospora sojina (No. conidia.cm²)

\begin{tabular}{|c|c|c|c|c|c|c|c|}
\hline Substrates & \multicolumn{3}{|c|}{ With filter paper } & \multicolumn{3}{|c|}{ Without filter paper } & Means \\
\hline Potato dextrose agar & A $11.1 \mathrm{a}$ & A 9.8 a & & A $8.5 \mathrm{a}$ & A 8.35 a & & 9.4 \\
\hline Soybean leaf extract agar & A $8.59 \mathrm{ab}$ & A $9.71 \mathrm{a}$ & & B $7.6 \mathrm{ab}$ & A 9.9 a & & 8.9 \\
\hline Soybean seed extract agar & A $11.1 \mathrm{a}$ & A $10.3 \mathrm{a}$ & & B $6.12 \mathrm{ab}$ & A 10.6 a & & 9.5 \\
\hline Tomato extract agar & A 9.7 a & A $9.1 \mathrm{ab}$ & & A 9.6 a & A 6.7 a & & 8.7 \\
\hline Oats flour agar & A 10.7 a & A $9.7 \mathrm{ab}$ & & B $7.8 \mathrm{ab}$ & A $8.2 \mathrm{a}$ & & 9.1 \\
\hline Soybean flour agar & A $3.7 \mathrm{c}$ & A $1.2 \mathrm{~b}$ & & A 8.2 a & B $0.0 \mathrm{c}$ & & 3.2 \\
\hline V-8 agar & A $11.4 \mathrm{a}$ & A $11.5 \mathrm{a}$ & & B $2.5 \mathrm{~b}$ & A 4.12 b & & 7.3 \\
\hline \multirow[t]{2}{*}{$\overline{\text { Means }}$} & $9.04 \mathrm{~A}$ & $8.8 \mathrm{~B}$ & & $7.4 \mathrm{~A}$ & $6.6 \mathrm{~A}$ & & \\
\hline & \multicolumn{2}{|c|}{ A 8.94} & & \multicolumn{3}{|c|}{ B 7.6} & \\
\hline
\end{tabular}




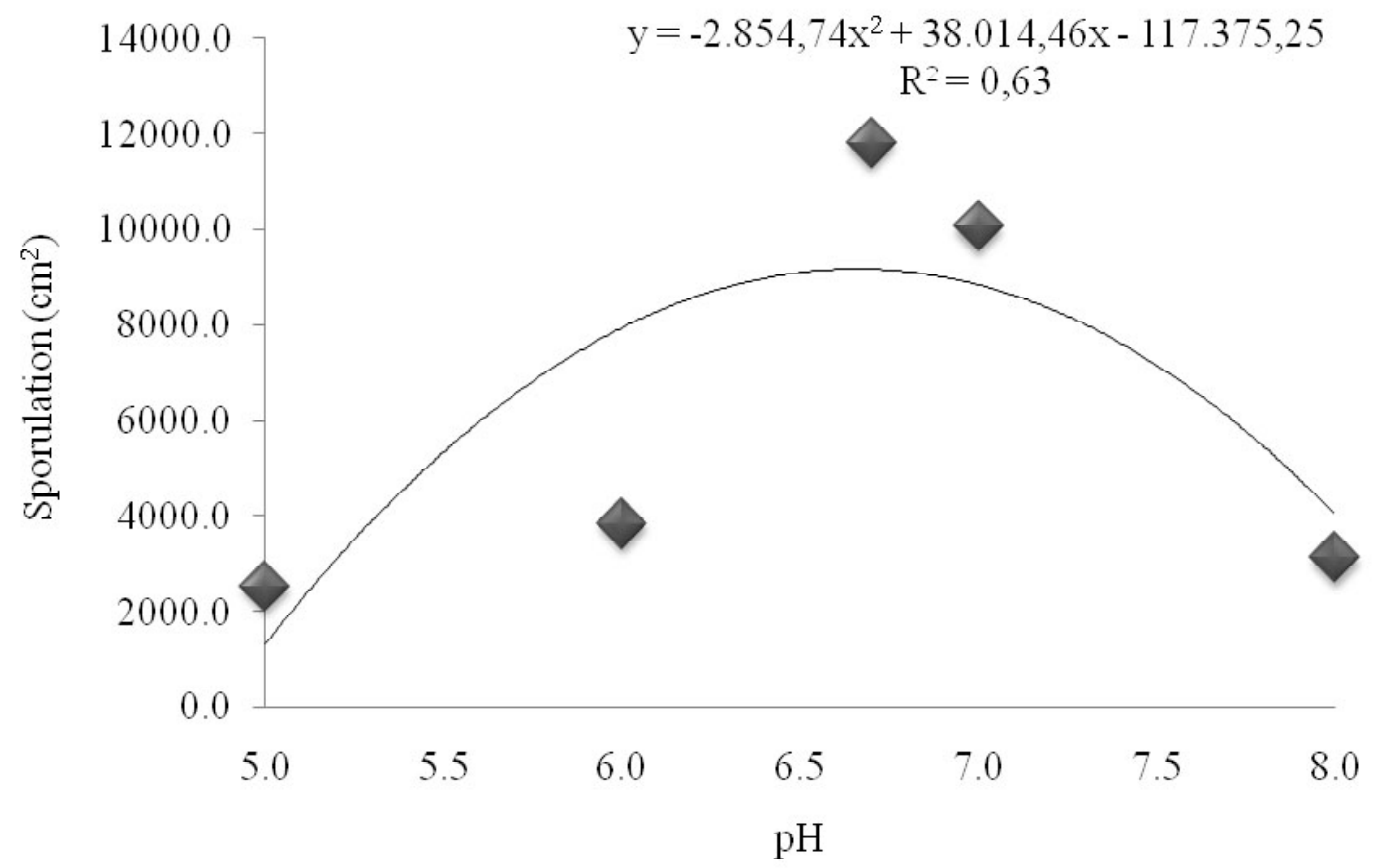

Figure 5. Effect of the $\mathrm{pH}$ of substrates on the sporulation (conidia number. $\mathrm{cm}^{-2}$ ) of Cercospora sojina on V-8 agar at $25 \pm 2{ }^{\circ} \mathrm{C}$.

\section{REFERENCES}

1. Agrios, G. N. Plant pathology. $5^{\text {th }}$ ed. Oxford: Academic Press, 2005. 948 p.

2. Aguirre, N.; Villamizar, R. L.; Espinel, C. C.; Cotes P. A. M. Efecto del $\mathrm{pH}$ y de la actividad de agua sobre el desarrollo de Nomuraea rileyi (Hyphomycetes). Revista Colombiana Entomologia, Bogotá v. 35, n. 2, p. 138-144, 2009.

3. Akem, C. N.; Dashiell, K. E. Effect of planting date on severity of frogeye leaf spot and grain yield of soybean. Crop Protection, Oxford, v.13, n. 8, p. 607-610, 1992.

4. Alexopoulus, C. J. Introductory mycology. $2^{\text {nd }}$ ed. New York: Wiley, 1952. $613 \mathrm{p}$

5. Bean, G.A. Prevalence of Curvularia pallescens and Helminthosporium spp. pathogenic on blue grass in Washington D.C., Phytopathology, St. Paul, v. 54, p. 888, 1964.

6. Carmona, M.; Scandiani, M. Epidemias de la mancha ojo de rana en la Región Pampeana: Caracterización y manejo. In: Congreso Nacional de Aapresid 170, 2009. Rosario, Santa Fe. Available at: $<$ http://agro.fauba.info/files/carmona_aapresid.pdf $>$. Accessed on: 16 Set. 2009

7. Companhia Nacional de Abastecimento (CONAB) 2009 - Acompanhamento da safra brasileira de grãos 2010/2011 - Quarto levantamento - janeiro 2011. Available at: http://www.conab.gov.br/ conteudos.php? $\mathrm{a}=1028 \& \mathrm{t}=2$. Accessed on: 5 Apr. 2011 .

8. Cortés, V. G. Introducción a la microbiología, $2^{\text {da }}$. ed., San José, Universidad Estatal a Distancia, 2005. 243 p.

9. Fernandez, M. R. Manual para laboratório de fitopatologia. Passo Fundo: Centro Nacional de Pesquisa de Trigo/Embrapa, 1993. $128 \mathrm{p}$.

10. Lukens, R. J. Conidial production from filter paper culture of Helminthosporium vagans and Alternaria solani. Phytopathology, St. Paul, v. 50, p. 867-868, 1990.

11. Macdonald, W. C.; Martens, J. W. Leaf and stem spot of sunflowers caused by Alternaria zinniae. Phytopathology, St. Paul, v.53, n.1, p. 93-96, 1963.

12. Argentina. Ministerio de Agricultura, Ganadería y Pesca de la Nación (MAGyP). 2011. Available at: http://www.minagri.gob.ar/SAGPyA/ agricultura/cultivos en la argentina/01-mapa principales_cultivos/

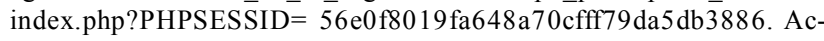
cessed on: 7 Apr. 2011.

13. Minussi, E.; Kimati, H. Esporulação de Colletotrichum graminicola (Ces.) Wils. do sorgo. Revista Centro Ciências Rurais, Santa Maria, v. 8, n. 4, p. 347-352, 1978.

14. Tuite, J. Plant pathological methods. Minneapolis: Burges Publishing. 1973. $73 \mathrm{p}$.

15. Veiga, P. Cercospora sojina Hara: obtenção de inoculo, inoculação e avaliação da resistência em soja [Glycine max (L.) Merril]. 1973. 30 p. Dissertação (Mestrado em Agronomia)-Escola Superior de Agricultura Luiz de Queiroz, Piracicaba. 